\title{
The Development of the Black Sea Straits Regulation of International Navigation
}

\author{
Roman Dremliuga ${ }^{1}$ \\ ${ }^{1}$ School of law, Far Eastern Federal University, Vladivostok, Russia \\ Correspondence: Roman Dremliuga, School of law, Far Eastern Federal University, Vladivostok, Russia. Tel: \\ 79-1-4707-1474. E-mail: dremliuga.ri@dvfu.ru
}

Received: December 23, 2014

Accepted: January 26, 2015 Online Published: April 22, 2015

doi:10.5539/ass.v11n12p269

URL: http://dx.doi.org/10.5539/ass.v11n12p269

\begin{abstract}
The Black sea straits as part of significant sea root were long time targets of the international politics and law. Regime constructed by Montreux Convention of 1936 was stable during decades but since 90-s Turkey unilaterally changed the rules. Objectively the new Turkish Regulations were a big step to prevent pollution, to improve the safety of vessel traffic and to ensure the safety of navigation through the mentioned straits. But it still has problematic provisions that breach the Montreux convention and modern principles of the law of the international navigation. Author tries to find limits established by the international law in this area because environmental reasons should not justify unjust actions. The Black sea straits case shows us how it is difficult to find balance between claims of user states and littoral states.
\end{abstract}

\section{Introduction}

The legal status of the international straits is a very significant issue for the world navigation because some of the straits have economic and strategic importance. Major navigation routes related to Russia pass through such straits. Transparency and predictability of navigation regulation impact perspectives of shipping development in the country. Perhaps the most important group of straights for Russia and other Black sea states is the Black Sea straits. They are the only way to access large international navigation routes from South-West of Russia. The Black Sea straits consist of the Bosporus strait and the Dardanelles strait and they connect the Black Sea and the Mediterranean Sea.

The Bosphorus is 15 nautical miles long and, at its narrowest point, it is 0,3 nautical miles wide, and its maximum width is 2 nautical miles. It divides Istanbul into two parts. It joins the Black Sea to the Sea of Marmora. The Dardanelles is the continuation of the Bosphorus. It is 35 nautical miles long, with a minimum width a little over one nautical mile, and a maximum width of 3.5 nautical miles, it connects the Sea of Marmora with the Aegean Sea. Depth is approximately $50 \mathrm{~m}$ (Martín, 2010, p. 78).

According Article 35 of the United Nations Convention of the Law of the Sea provisions of the Part III "Straits used for international navigation" cannot influence the legal regime in straits where passage is regulated by long term international convention in force especially relating to such straits" and The Black Sea straits already have such agreement. It means that in the first place we should define the legal regime of straits in compliance with the convention that was applied there before.

\section{Historical Aspects}

It should be noted that nowadays Republic of Turkey did not sign the UNCLOS (United Nations Convention of the Law of the Sea) (See Status of UNCLOS). Turkey is not a party to this agreement, and is not promising to take part in UNCLOS convention in the near future. The transit passage rule does consequently not bind Republic of Turkey as treaty norm, and it is not fully transparent whether it applies as customary rule in its integrity (Rothwell \& Bateman, 2000). The main applicable international law act that defines the legal status of these straits is the Convention regarding the regime of the straits (the Montreux convention) of 1936. This Convention just contains twenty nine articles and defines rules of navigation through the Black Sea straits. The first article establishes that Parties of the Convention appreciate and ratify the main rule of freedom of transit and navigation by sea in the Black sea Straits. The exercise of transit freedom was regulated by the rules of the Montreux Convention of 1936. 
The Montreux agreement replaced the Turkish Straits regime established by the 1923 Lausanne Treaty and led to basic changes. This agreement retained the principle of freedom of passage and navigation for all merchant vessels, but the new Convention restored full sovereignty privilege over the Black sea straits to Turkey Republic. Most significant thing that the proscription against militarizing the Straits by the Turkish Republic was withdrawn and it permitted government to establish the military presence for self-defense. While foreign navy vessels still could enjoy privilege of passage, convention regarded interest of Turkey and riparian states security issue. It should be noted that the function that belonged to the international commission were handed over to the government (Gündüz \& Nilüfer, 1998).

The Montreux Convention, as mentioned on the official web-site of the Ministry of foreign affairs of the Turkish Republic, is an indispensable part in scope of regional security and stability. This agreement has been appropriately and without bias implemented by the Republic of Turkey for more than seventy years (See Implementation of the Montreux Convention).

The Montreux Convention states that merchant vessels have right of free transit and navigation in the Straits twenty-four hours, under any kind of flag and with any type of cargo. Vessel just should follow small formalities, such as international sanitary regulations, and small taxes empowered by Annex. Agreement underlines that pilotage and towage are not compulsory for the nongovernmental vessels passing through the Black sea Straits. The captain just has to inform Turkey authorities about name, nationality, tonnage, destination e.tc. It means full freedom of transit without any interventional of coastal state.

According to Articles 4 and 5 of the Convention freedom of merchant navigation remains also in case of war if the Republic of Turkey is not being belligerent. Even if Turkey takes part in war nongovernmental vessels not belonging to a country at war with it shall enjoy freedom of transit and navigation in the Straits on the condition that it does not, in any way, assist the enemy. These provisions correspond to the main principals of the Law of the Sea and do not permit coastal state interfere in merchant navigation regardless of flag, cargo and tonnage of a ship. Moreover, clauses of the Montreux convention long time supported development of shipping and provide a balance of power in the Black Sea region. The main achievement of this international act is the absence of sufficient conflicts in the area until recently.

\section{Discussions}

The situation changed on the 13th of March 1994 when a ship accident happened and Turkey unilaterally tried to make rules of navigation tougher. It was very famous accident when the tanker, Nassia, collided with the dry bulk carrier, Shipbroker, in the Bosporus strait (strait of Istanbul). According the media the Nassia dangerous drifted close to the European side of strait and her cargo burned and spilled until the Turkish authorities managed to tow away the flaming wreck. It caused that shipping through the Istanbul Strait was banned for week and more than 500 vessels had to wait for transit passage (Yücel, 2001).

After this incident the Republic of Turkey enacted the Marine Traffic Regulations for the Turkish Straits and the Marmara Region which according to our opinion contravenes some clauses of the Montreux Convention. For instance, Article 1 of the Regulations contains the item that Maritime traffic in the Straits may be temporarily stopped by the Turkish authorities due to a lot of reason such as some underwater construction or even scientific and sports activities and pursuing criminals etc. It should be noted that Turkish legislator uses phrase "and in other similar cases" in the end of this provision. It means that Black sea states could be cut off from world navigational routes due to a wide circle of reasons but some of countries have no other sea routes to global sea space and so it indirectly intervene their right of access to this area and their right to free transit passage that is guaranteed by international agreement ratified by Turkey.

Besides according to Article 31 of the Regulation foreign vessels are recommended for safety purposes to take a pilot and the Administration of strait may establish compulsory pilotship requirements in settled areas in the Black sea Straits and the Marmara region. This rule is directly opposite to the Convention that claims the optional character of pilotage (See Article 2 of the Convention).

The Article 25 of the Regulations requires that vessels which cross over the specified traffic lanes may be fined but it is not implied by the Montreux Convention because the Article 1 claims freedom of transit and navigation in the Straits.

In addition, the Montreux Convention calls for freedom of transit and navigation in the Straits under any flag and with any type of cargo, without any formalities except sanitary rules. The Regulations restricted navigation of some vessels on the contrary. For instance, Article 42 claims that when a large vessel with hazardous cargo enters the Strait, another vessel which carries hazardous cargo has not enter the Strait until the previous vessel 
has departed. Also, Article 52 requires that when a large vessel with hazardous cargo enters the Strait, a similar vessel which moves from the contrary direction has not enter the Strait until the previous vessel has departed. There have to be a distance of at least 20 nautical miles between two vessels with hazardous cargo which are moving in the same direction. This provision creates a interruption of traffic through the Turkish Straits and provides additional threats to navigation.

For instance, an uncontrollable crowd of drifting vessels with hazardous cargo appeared near strait entrance (at least 20 vessels) (Blagodelsky, 2008). Since the introduction of regulations for navigation in the Straits by Turkey, from 1 July 1994 to 1 July 1998512 ships owned by the Novorossiysk Shipping Company alone, sailing under the Russian flag, were detained due to suspension of two-way traffic and introduction of one-way traffic by the Turkish Authorities (detentions due to bad visibility and weather are not included). Forced idleness of the ships operation was 2523 hours and the Company's losses constituted US $\$ 1,338,122$. This situation isn't considered by Russian government as an acceptable situation and Russia proclaimed it in MSC meetings (IMO Doc. MSC 70/11/11).

Turkey even changed the names of straits and instead of the generally accepted Bosporus strait and Dardanelles strait it uses the Strait of Istanbul and the Strait of Canakkale (See Article 2). But these names are used since ancient times and marked on maps many thousands of times.

The Regulations also have other discrepancies to the Montreux Convention that increase costs of navigation, create new threats and leads to instability at the Black Sea region. The Russian Federation (See MSC 63/7/15), generally supported by a number of delegations, noted that the rules for ships navigating in the Straits of Istanbul and Canakkale, proposed by Turkey have a number of rules which contradict universally recognized rules of the Law of the Sea and especially the terms of the Montreux Convention. There was the opinion that rules of the Regulations to be adopted by the Organization should conform completely to the 1936 Montreux Convention, the United Nations Convention on the Law of the Sea of 1982, the provisions of customary law on straits used for international navigation etc.

In 1995, the IMO Assembly adopted resolution A.827(19) and it brought into force Rules and Recommendations on Navigation through the Strait of Istanbul, the Strait of Canakkale (the Black sea straits) and the Marmara Sea. The Assembly of the International Maritime Organization emphasized that Rules and Recommendations are established totally for the purpose of safety of navigation and environmental protection and are not intended in any way to touch or trespass against the privileges of any ship which follows international maritime law, including the United Nations Convention on the Law of the Sea and the Montreux Convention, using the Straits. Moreover any national regulations proclaimed by the coastal State should be in absolute conformity with the rules, norms and regulations adopted by International Maritime Organization. After making protests against the Regulations to the International Maritime Organization by the some members of the Montreux convention Turkey enacted the Maritime traffic regulations for the Turkish straits Regulations at 1998 (the new Regulations).

The new Regulations established Traffic Separation Schemes (TSS) and boundary lines of the Turkish Straits. And according to The International Convention For Preventing Collision at Sea (COLREGS 72) Reg. (10) (Article 3 of the new Regulations) requires vessels navigating within the Straits to be in compliance with the Annexes in force of Marpol 73/78 Convention (Articles 29). It also takes into consideration some other international law acts and recommendations of the International Maritime Organization. But it should not mislead you this Regulations also puts obstacles in the way of international navigation through Bosporus strait and Dardanelles strait. For example, it cancels permission-based procedures of large oilers passing.

First of all, the new Regulations uses Turkish names instead of names generally accepted in the world (Article 2) which does not breach international law but it creates additional inconveniences. Also, according to the new Regulations of the Republic of Turkey authorities have the possibility to suspend the traffic for the straits. Traffic in the Straits may temporarily be suspended by the Administration in plenty of cases (Sea article 20) and some of reasons for suspension are defined pretty uncertain. For instance, traffic in Straits could be interrupt in case of construction works for the common wealth of the public or for public security reasons.

Furthermore, the Turkey limits some types of vessels from passing through straits. For example, Article 25(d) claims that when vessel leading towards the south with dangerous cargo enters from the north of the Istanbul Strait, no vessel leading towards the north is permitted with the same cargo until the first mentioned reaches to Istanbul Bogazi Bridge.

Some Russian authors have noted correctly that international law has no restrictions for vessels with dangerous cargo (Kolodkin, Guculyak, \& Bobrova, 2007). For instance, the United Nations Convention on the Law of the 
Sea of 10 December 1982 states that vessels carrying dangerous or noxious substances or materials may be required to limit their passage to prescribed sea lanes (Article 22 part 2 of the UNCLOS) and that such foreign vessels, when innocently pass through the territorial sea, carry documents and observe special precautionary measures established for ships of this type by international agreements (Article 23 of the UNCLOS). The UNCLOS Convention does not provide any reasons to ban the innocent passage of such vessels.

Objectively the new Turkish Regulations were a big step to prevent pollution, to improve the safety of vessel traffic and to ensure the safety of navigation through the mentioned straits. But it still has problematic provisions that breach the Montreux convention and modern principles of the law of the international navigation.

Next, significant steps were improvement of (TSS) traffic separation schemes and other routing measures and mandatory ship reporting systems were adopted to establish of infrastructure that aims to ensure the uninterrupted flow of traffic through the Strait and the averting of safety and environmental risks. The establishment, by the Turkish Government, of a new vessel traffic service to supervise and assist maritime navigation in Straits contributed to the improvement of the overall situation. It should be noted that more the Russian Federation than once declared that the root of the problem is not in the strictness of domestic law but the improvement of strait infrastructure. But we still consider that safety measures in the Straits should consist of the amended TSSs in the area (annex 1 to annex 10 of NAV 43/15), the revised Rules and Recommendations (annex 2 to annex 10) and recommendations addressed to the Government of Turkey (annex 3 to annex 10) which hopefully will be implemented. Maritime safety committee (70th session, Agenda item 11, MSC 70/11/11). Russia repeatedly offered to help Turkey while it was putting into operation the Vessels Traffic Services (VTS) system in the Black Sea Straits. For instance, the Russian Federation claimed that it was open to cooperate with the Turkish Maritime Administration in this area and was ready to assist in training of the operators at the Russian VTS Centers (Maritime safety committee, 78th session, Agenda item 25. MSC 78/25/4. 5 March 2004).

Recently, the Republic of Turkey enacted new directives that described the enforcement conditions of Turkish Straits Maritime Traffic Order Regulations. This act complies more with the international law, IMO conventions and recommendations but it still contains a lot of disputed terms. The Turkey reaffirmed its own ability to suspend the traffic for straits for a wide circle of reasons. For instance, Article 14 (Passage Rules of the Vessels) part A. of the Directives establishes that dangerous cargo carrying vessels shall not be encountered with any other ship with a full length more than $150 \mathrm{~m}$ or equal. Also, dangerous cargo carrying vessel not be allowed into the Strait from the opposite direction.

It should be noted that Turkish authorities use right to suspension very actively, for instance, they suspend the Dardanelles' vessel passages 11 times from 1 April 2013 till 9 April 2013 (Navigation in the strait of Dardanelles). Sometimes it takes more than 6 hours, the passages were suspended due to LNG tanker MOURAD DIDOUCHE (L.O.A.= 278,82 m.) passages on 09 April 2013 for Northbound from 13:00 to 20:00 local time. Entering Dardanelles from Northern Entrance was on 09 April 2013 at 17:00 local time (Navigation in the strait of Dardanelles).

\section{Conclusions}

Since adoption of Marine Traffic Regulations for the Turkish Straits and the Marmara Region 1994 the Russian Federation has taken a position against unilateral changes of straits navigational rules. Russia supports that transformation of international law or enacting of new multilateral agreement is possible only by taking into consideration wills of all Black sea states. Choosing a legal course of action with respect to the Black sea straits, Russia sequentially achieved the establishment of a secure, legitimate and fair regime in this area. This experience demonstrates the power of modern international law that can provide for peaceful dispute settlement, due to existence of international institutions, like IMO. According to exist tendency the Republic of Turkey will improve these mentioned disputable clauses and the rules of navigation through the Black Sea Straits will comply with the Montreux convention, other international agreements and requirements of merchant navigation in future.

Also Black sea straits case shows us how it is difficult to find balance between claims of user states and littoral states. Positions of both sides are based on the provisions of the international law and look well-grounded.

But probably it is time to revise and improve old international agreements according to modern conditions and needs of maritime safety and environment. Example of the Black sea straits shows us that it is necessary to take into account complex system of factors to establish satisfying rules of navigations in such significant Straits.

\section{References}

Blagodelsky, S. V. (2008). Legal status of the Black Sea straits at modern age. Retrieved from 
http://flot3000.com/ru/history/1387 (Russian language)

Gündüz, A., \& Nilüfer, O. (1998). Turkey's authority to regulate passage of vessels through the Turkish straits. Journal of International Affairs (Perceptions), 3(2). Retrieved November 10, 1998, from http://sam.gov.tr/wp-content/uploads/2012/02/GunduzAybayNiluferOral.pdf

IMO Doc. MSC 70/11/11 9. October 1998. With reference to paragraphs 5.49 to 5.52 of the Committee's report MSC 69/22, the Russian Federation submits its comments and proposals on the matter.

Implementation of the Montreux Convention. Retrieved from http://www.mfa.gov.tr/implementation-of-themontreux-convention.en.mfa

Kolodkin, A. L., Guculyak, V. N., \& Bobrova, Y. V. (2007). The World ocean. The International law regime. Main issues (p. 227).

López Martín, A. G. (2010). International Straits: Concept, Classification and Rules of Passage, 2010. $\mathrm{http}: / / \mathrm{dx}$. doi.org/10.1007/978-3-642-12906-3

Marine Traffic Regulations for the Turkish Straits and the Marmara Region. Retrieved November 10, 2014, from http://www.un.org/depts/los/LEGISLATIONANDTREATIES/PDFFILES/TUR_1994_Regulations.pdf

Navigation in the strait of Dardanelles. Retrieved from http://www.dardanelshipping.com/arsiv.asp?tip= $6 \&$ baslik $=$ Strait

Resolution of IMO Assembly A.827(19). Retrieved November 10 from official site of IMO. Retrieved from http://www.imo.org/blast/blastDataHelper.asp?data_id=22630\&filename=A827(19).pdf

Rothwell, D. R., \& Bateman, S. (Eds.). (2000). Navigational Rights and Freedoms and the New Law of the Sea. The Hague.

Status of UNCLOS singing. Retrieved November 10, 2014, from http://www.un.org/Depts/los/reference_files/ status2010.pdf

Turkish Straits Maritime Traffic Order Regulations Enforcement Directives (not official translation). Retrieved from http://www.infomarine.gr/maritime-news/rss-news-publications/57-new-regulations/937-turkey-turkis h-straits-maritime-traffic-order-regulations.html

UNCLOS United Nation Convention on the law of the sea 1982 official text. Retrieved November 10, 2014, from http://www.un.org/Depts/los/convention_agreements/texts/unclos/unclos_e.pdf

Yücel, G. (2001). Regulation of the passage through the Turkish straits. Journal of International Affairs (Perceptions), 6(1). Retrieved November 10, 2014, from http://sam.gov.tr/wp-content/uploads/2012/ 02/YucelGuclu.pdf

\section{Copyrights}

Copyright for this article is retained by the author(s), with first publication rights granted to the journal.

This is an open-access article distributed under the terms and conditions of the Creative Commons Attribution license (http://creativecommons.org/licenses/by/3.0/). 